\title{
Insects reared from logging residue on clear-cuts
}

\author{
Karolina Nittérus, Bengt Gunnarsson \& Emma Axelsson
}

Nittérus, K., Gunnarsson, B. \& Axelsson, E. 2004: Insects reared from logging residue on clear-cuts. — Entomol. Fennica 15: 53-61.

Coniferous and deciduous logging residue ("slash") was collected from six 1year old and six 4-year old clear-cuts in South-West Sweden during the spring of 2002. In the laboratory, insects were emerged under standardised conditions. Insects emerged in $41 \%$ of the rearing-tubes with 1-year old slash. In 4-year old slash, $54 \%$ of the tubes contained insects. The most successfully emerged order was Coleoptera, represented by 10 families, 22 species and 425 individuals. The second most abundant order was Hymenoptera. The most abundant Coleoptera family was Curculionidae that comprised $48 \%$ of all the beetles. Four distinct species groups among Coleoptera were found, each group being separated by slash age and tree category (deciduous/coniferous). Significantly more species were found in the 4-year old deciduous slash, compared to the 1-year old. In coniferous slash, there was a tendency for more species in the 1-year old slash than in the 4-year old. The results suggest that slash is valuable as breeding substrate and/or food supply to the beetle fauna on clear-cuts.

K. Nittérus* \& B. Gunnarsson, Dept. of Applied Environmental Science, Göteborg University, Box 464, SE 40530 Göteborg, Sweden; * E-mail: karolina. nitterus@miljo.gu.se

E. Axelsson, Mandolingatan 39, 42145 Västra Frölunda, Sweden

Received 28 August 2003, accepted 19 November 2003

\section{Introduction}

A large-scale program for commercial use of logging residue ("slash") as bio-fuel has recently been started in Sweden. Logging residue is defined as the woody biomass, including tree tops and branches $(<10 \mathrm{~cm}$ in diameter), that is created during harvest of timber and left behind after clear-cut harvesting (Egnell et al. 2001). Volumes of dead wood have been greatly reduced in managed forests in Scandinavia (Fridman \& Walheim 2000, Siitonen et al. 2000), which has led to an increase in the number of threatened insect species (Jonsell et al. 1998, Ehnström \& Axelsson 2002, Similä et al. 2002). Earlier studies have mainly been focused on coarse woody debris (CWD) and the associated saproxylic fauna. However, the importance of the finer fractions of the woody debris, like logging residue left behind on clearcuts, is not well examined. At a local scale, intensive slash removal might cause severe damage on the invertebrate populations that utilize the finer woody fractions for nutrition and/or shelter.

Slash on clear-cuts was examined by Pettersson (1974), who found that up to five species of bark beetles were using the fine fractions of the fresh coniferous material for the development of eggs and larvae. In a study by Schroeder and Eidmann (1993), fresh spruce and pine tops created by snow breakage were attacked by bark 


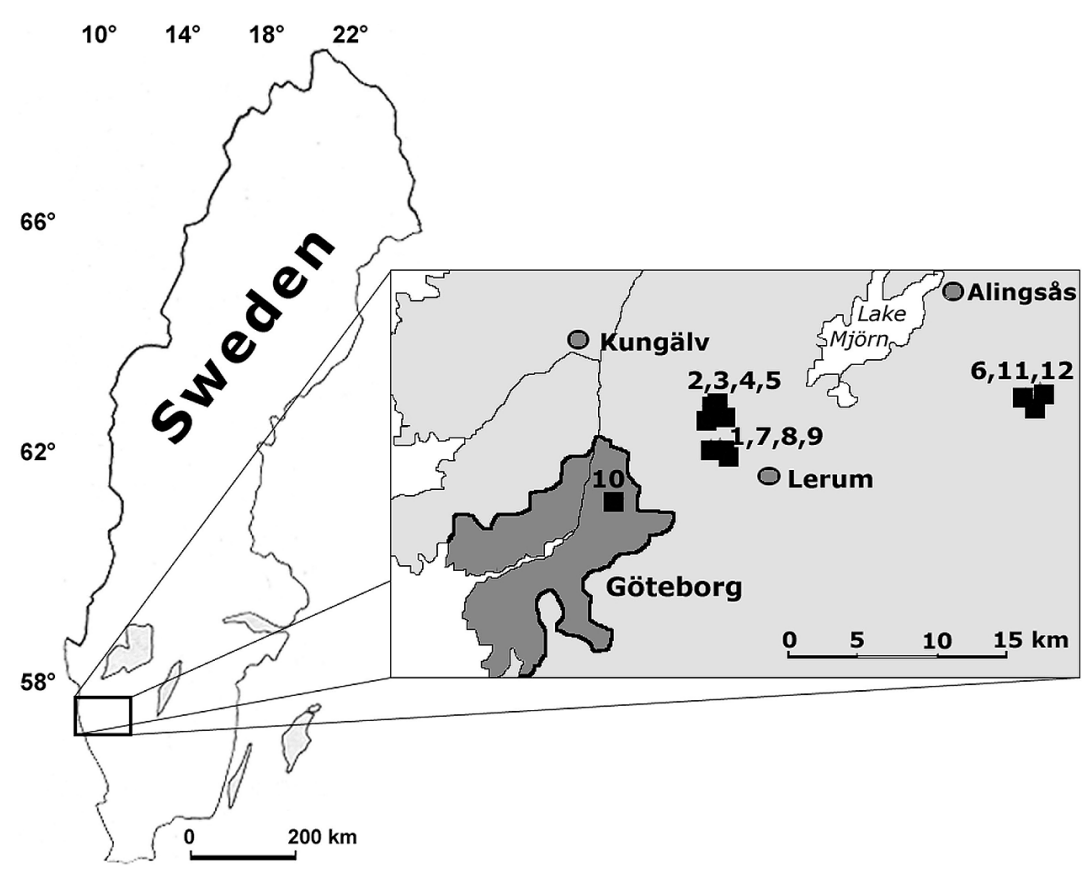

Fig. 1. Map of the study sites. beetles and weevils during the first two-year period. Martikainen et al. (1996) made comparisons of old-growth and production sites in Finnish and Russian Karelia and found that the woody material in managed areas (i.e. logging residue and pine stumps) harboured mainly light-preferring bark beetles. However, to our knowledge, there are no investigations focusing on the fauna dwelling within logging residue left behind on clearcuts specifically.

A general problem in studies of saproxylic insects is to find an appropriate method for investigating the fauna dwelling within the wood. When estimating the effectiveness of different trapping methods, it is important to search for new and quantitatively improved methods, e.g. related to specific microhabitats (Komonen 2003). Window trapping was demonstrated by Martikainen and Kouki (2003) to underestimate the occurrences of rare or threatened species, thus not being an ideal method for investigations of total beetle diversity. Ehnström and Axelsson (2002) mention insect rearings from collected woody material (e.g. bark, pieces of CWD and polypore fruiting bodies) as widespread among entomologists and species collectors. Palm (1959), Økland (1996), Jonsson et al. (1997), Jonsell (1999), Komonen et al. (2000), and Ehnström and Axels- son (2002) have used different rearing methods for examination of wood-dwelling beetles. However, insect rearings have rarely been used for the finer fractions of wood, i.e. slash.

The aims of the present study were (a) to study taxonomic composition of insects emerged from logging residue on clear-cuts, (b) to examine the species composition of Coleoptera between two age classes ( 1 and 4 years) and five tree species of slash, and (c) to examine the applicability of a quantitative rearing method on the beetle fauna.

\section{Material and methods}

Mature forests in southwestern Sweden are often fairly young, 70-90 years, and contain mainly coniferous trees, although substantial amounts of deciduous trees may occur. The areas selected for this study were highly affected by forestry and no reserves existed in the close vicinity of the stands. Removal of slash for bio-fuel was not performed on the investigated sites.

All the studied clear-cuts had a mixture of coniferous and deciduous trees $(>10 \%$ of the total number of trees) before logging. The sites were divided into 1-year and 4-year old stands, where 
Table 1. Study sites. Nr. $=$ site number, Loc. $=$ sampling locality, Comm. $=$ local community, Date $=$ collecting date, Size $=$ size of the clear-cut in ha, Age $=$ stand age i.e. years since logging, Samples $=$ number of samples per site, Tree spp. $=$ collected tree species (one sample per tree species in each site): $\mathrm{BS}=$ Betula species, $\mathrm{PA}=$ Picea abies, PS = Pinus sylvestris, PT = Populus tremula, $\mathrm{QS}=$ Quercus species, $\mathrm{SA}=$ Sorbus aucuparia, $\mathrm{SS}=$ Salix species, $\mathrm{TC}=$ Tilia cordata.

\begin{tabular}{|c|c|c|c|c|c|c|c|}
\hline Nr. & Loc. & Comm. & Date & Size & Age & Samples & Tree spp. \\
\hline 1 & Kyrkåsen & Göteborg & 12.III. & 3.5 & 4 & 5 & PS, PA, BS, QS, SA \\
\hline 2 & Galgaberget & Göteborg & 12.III. & 2.5 & 4 & 5 & PA, PS, BS, QS, PT \\
\hline 3 & Getasdal & Göteborg & 12.III. & 2.6 & 4 & 4 & PA, PS, BS, QS \\
\hline 4 & Mjörnås & Göteborg & 27.III. & 1.4 & 4 & 5 & PA, PS, BS, QS, PT \\
\hline 5 & Mjörnåsen & Göteborg & 27.III. & 1 & 4 & 4 & PA, PS, BS, QS \\
\hline 6 & 140-Alingsås & Alingsås & 10.IV. & 8.1 & 4 & 3 & PA, PS, BS \\
\hline 7 & Häljered & Göteborg & 20.III. & $\sim 1$ & 1 & 5 & PA, PS, BS, QS, PT \\
\hline 8 & Småkulla & Göteborg & 25.III. & 3.4 & 1 & 4 & PA, PS, BS, QS \\
\hline 9 & Gräsåsen & Göteborg & $20.1 I I$. & 4.3 & 1 & 4 & PA, PS, BS, QS \\
\hline 10 & Gärdsås kulle & Göteborg & 25.III. & 0.6 & 1 & 5 & PA, PS, BS, QS, SA \\
\hline 11 & 150-Alingsås & Alingsås & 10.IV. & 7.8 & 1 & 5 & PA, PS, BS, SA, TC \\
\hline 12 & 89-Alingsås & Alingsås & 10.IV. & 0.6 & 1 & 6 & PA, PS, BS, QS, SA, SS \\
\hline
\end{tabular}

the "age" equals the number of years after logging. However, the exact timing of each logging event differed. In total, twelve clear-cuts were studied, six of these were 1-year old and six were 4-year old (Table 1). Nine of the study sites were in Göteborg municipality and three in Alingsås (Fig. 1). Sampling was carried out during March and April in 2002.

We collected one sample, each consisting of slash of 3-5 tree species, from each study site (Table 1). The tree species selected were Norway spruce (Picea abies), Scots pine (Pinus sylvestris), birch (Betula spp.), oak (Quercus spp.) and other deciduous tree species present, viz. aspen (Populus tremula), rowan (Sorbus aucuparia), willow (Salix spp.) and linden, Tilia cordata).

Sampling was done along a North-South transect that was established in the middle of each clear-cut (Fig. 2). Along this transect, we collected one sample of each tree species within circles of 5-m diameter. Starting from the centre of the circle and moving outwards, the first slash fraction found was collected. If more than one branch of the same tree species was available, random selection was used. If all tree species were not present within the first investigated circle, collection was continued in the next circle at 20-m distance until samples from at least three (but preferably all five tree species) were col-

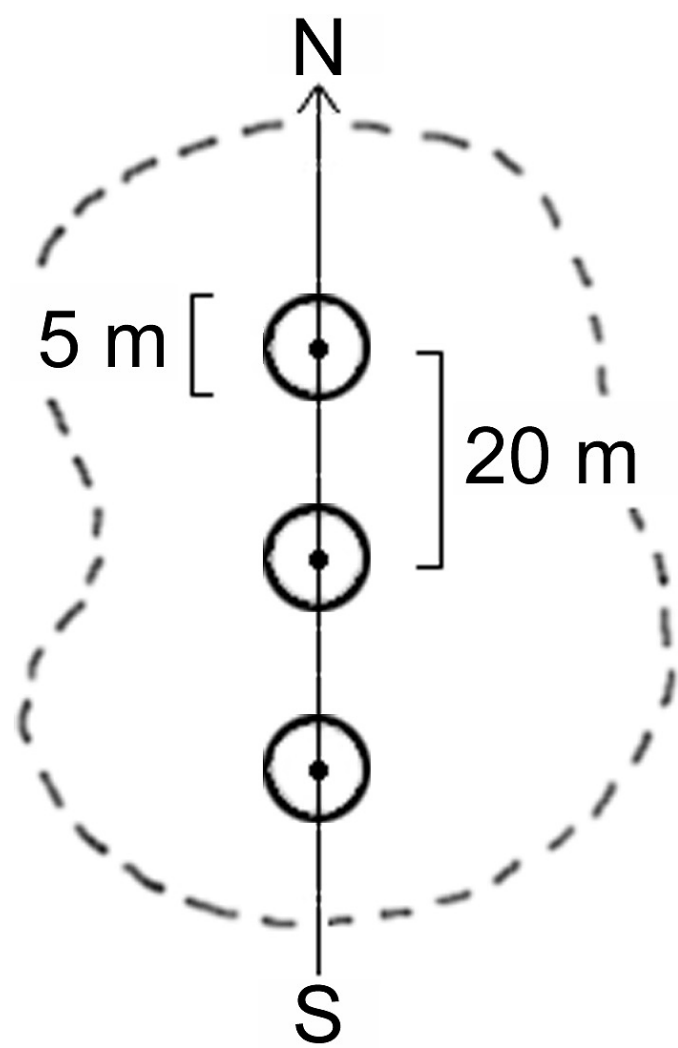

Fig. 2. Schematic illustration of the sampling method performed in field. 


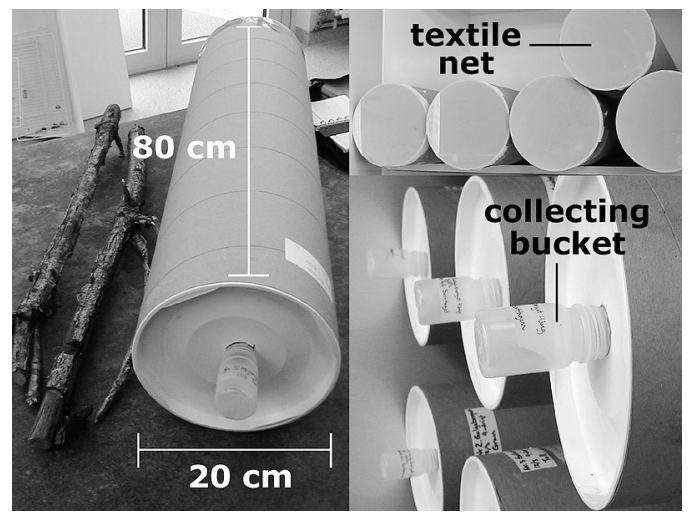

Fig. 3. Paper tubes for insect rearing.

lected on each clear-cut (Table 1). Tilia cordata and Salix spp. were not found on the 4-year old sites. The branches collected varied between 0.5 and $7 \mathrm{~cm}$ in thickness.

In the field, the woody material was immediately put into breathable paper tubes (Fig. 3). Until the start of the rearings, both ends of each tube were covered with plastic lids. In the laboratory, the plastic lids were switched to breathable, finemeshed textile nets (Fig. 3). After 7-8 days of aeration of the material in room temperature (17$20^{\circ} \mathrm{C}$ ), a plastic collecting bucket was placed at one end, turned to the light while the other end was kept away from the light (Fig. 3).

The material was left in the rearing-tubes for 7 weeks. After 2-3 weeks in the laboratory the invertebrates within the woody material in the tubes started to emerge. The collecting buckets were checked and emptied five days a week. Humidity of each tube and its contents were ensured by water spraying. After 7 weeks, the material was emptied onto a large plastic tray and each branch was searched through by hand to detect if individ-

Table 2. Emerged individuals from six insect orders.

\begin{tabular}{lcc}
\hline Order & Individuals & Percentage \\
\hline Coleoptera & 425 & 63.3 \\
Diptera & 107 & 15.9 \\
Hemiptera & 4 & 0.6 \\
Hymenoptera & 127 & 18.9 \\
Psocoptera & 4 & 0.6 \\
Thysanoptera & 4 & 0.6 \\
Total & 671 & 99.9 \\
\hline
\end{tabular}

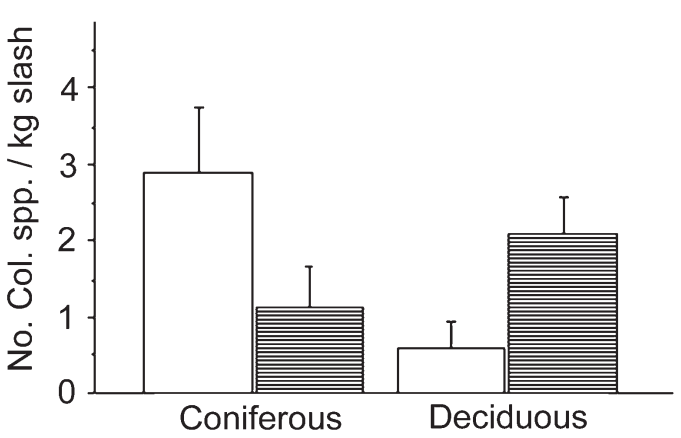

Fig. 4. Mean number ( $\pm \mathrm{SE}$ ) of Coleoptera species per $\mathrm{kg}$ slash for age categories 1-year (open bars) and 4year (hatched bars).

uals were still remaining in the tube or in the material. After the completion of the rearings, the slash was dried in laboratory ovens at $85^{\circ} \mathrm{C}$ for 24 hours and weighted on a digital balance. In the analysis, we corrected for unequal size of the slash by relating the number of species to the dry weight of slash.

The non-parametric Mann-Whitney $U$-test was used, because the dataset was small and not normally distributed. We employed the software StatView for Mac 5 (SAS Institute Inc. 1998).

\section{Results and Discussion}

Six different orders of insects plus a large number of spiders emerged from the slash (Table 2). Hymenoptera and Diptera made up $18.9 \%$ and $15.9 \%$, respectively, of the total number of emerged specimens. From here on, we will focus on Coleoptera as this was the predominant order (63.3\%).

In total, 22 species of Coleoptera, from ten different families emerged. Of these species, $45 \%$ were representatives of Curculionidae, dominated by the bark beetles (subfamily Scolytinae) (Table 3).

We analyzed the influence of the material age on species number (corrected for slash weight) in coniferous and deciduous logging residue, respectively. The coniferous material included spruce and pine, and the deciduous species included were oak and birch. Despite the rather low sample size, a significantly smaller (Mann-Whitney two-tailed $U$-test, $U=30, n_{1 y r}=11, n_{4 y r}=11, p$ 
Table 3. Emerged Coleoptera from slash, and their substrate requirements according to Ehnström \& Axelsson (2002).

\begin{tabular}{|c|c|c|c|}
\hline Family/subfamily & $\%$ & Species & Substrate \\
\hline Buprestidae: Agrilinae & 5 & Agrilus angustulus (Illiger) & $\begin{array}{l}\text { recently dead fine branches + slash } \\
+ \text { CWD of Quercus, Corylus }\end{array}$ \\
\hline Carabidae: Harpalinae & 5 & Dromius spilotus (Illiger) & $\begin{array}{l}\text { hibernating under bark on large } \\
\text { branches and stems of Pinus }\end{array}$ \\
\hline Cerambycidae: Cermbycinae & 9 & Clytus arietis (Linnaeus) & $\begin{array}{l}\text { older sun-exposed deciduous } \\
\text { branches + slash (diam. } 2-15 \mathrm{~cm} \text { ) } \\
\text { of Quercus, Fagus, Fraxinus, } \\
\text { Salix etc. }\end{array}$ \\
\hline Cerambycidae: Lamiinae & & Leiopus nebulosus (Linnaeus) & $\begin{array}{l}\text { recently dead, fine deciduous } \\
\text { branches + stems (diam. }<5 \mathrm{~cm} \text { ) of } \\
\text { Quercus, Corylus }\end{array}$ \\
\hline Colydiidae: Colydiinae & 5 & Synchita humeralis (Fabricius) & $\begin{array}{l}\text { recently dead deciduous wood of } \\
\text { Betula, Salix, Alnus }\end{array}$ \\
\hline Attelabidae: Rhynchitinae & 5 & Rhynchites cupreus (Linnaeus) & branches of Sorbus \\
\hline Curculionidae: Magdalinae & 45 & Magdalis barbicornis (Latreille) & $\begin{array}{l}\text { recently dead deciduous branches } \\
+ \text { wood (diam. 5-50 cm) of Prunus, } \\
\text { Sorbus, Malus etc. } \\
\text { recently dead, fine coniferous } \\
\text { branches + slash of Picea, Pinus }\end{array}$ \\
\hline Curculionidae: Hylesinae & & Tomicus minor (Hartig) & $\begin{array}{l}\text { thin bark on branches, smaller } \\
\text { stems and downed/standing CWD } \\
\text { of Pinus and occasionally Picea }\end{array}$ \\
\hline \multirow[t]{7}{*}{ Curculionidae: Scolytinae } & & Cryphalus abietis (Ratzeburg) & $\begin{array}{l}\text { recently dead fine branches + stems } \\
\text { of Picea and Pinus }\end{array}$ \\
\hline & & Crypturgus hispidulus (Thomson) & $\begin{array}{l}\text { downed and standing trees, CWD } \\
\text { of Picea, Pinus }\end{array}$ \\
\hline & & Crypturgus pusillus (Gyllenhal) & $\begin{array}{l}\text { downed and standing dead trees, } \\
\text { CWD of Picea and Pinus }\end{array}$ \\
\hline & & Orthotomicus suturalis (Gyllenhal) & $\begin{array}{l}\text { stems (old, burned) + slash left on } \\
\text { clear-cuts of Pinus, Picea }\end{array}$ \\
\hline & & Pityogenes bidentatus (Herbst) & $\begin{array}{l}\text { downed dead coniferous branches } \\
\text { of Pinus }\end{array}$ \\
\hline & & Pityogenes chalcographus (Linnaeus) & $\begin{array}{l}\text { downed dead coniferous branches, } \\
\text { slash, CWD of Picea, Pinus }\end{array}$ \\
\hline & & Pityogenes quadridens (Hartig) & $\begin{array}{l}\text { downed dead coniferous stems } \\
(\text { diam. }<20 \mathrm{~cm})+\text { slash of Pinus }\end{array}$ \\
\hline \multirow[t]{2}{*}{ Melyridae: Dasytinae } & 9 & Dasytes cyaneus Fabricius & $\begin{array}{l}\text { soft dead branches of Quercus, } \\
\text { Tilia, Fagus, Fraxinus }\end{array}$ \\
\hline & & Dasytes aerosus Kiesenwetter & $\begin{array}{l}\text { soft dead branches of Quercus, } \\
\text { Tilia, Fagus, Fraxinus }\end{array}$ \\
\hline Monotomidae: Rhizophaginae & 5 & Rhizophagus dispar (Paykull) & under bark of deciduous wood \\
\hline Nitidulidae: Cryptarchinae & 5 & Pityophagus ferrugineus (Linnaeus) & $\begin{array}{l}\text { recently dead coniferous } \\
\text { wood }\end{array}$ \\
\hline Staphylinidae: Aleocharinae & 9 & Leptusa ruficollis (Erichson) & deciduous wood \\
\hline Staphylinidae: Phloeoch & & Phloeocharis subtilissima Mannerheim & coniferous wood \\
\hline Total & 99 & & \\
\hline
\end{tabular}

$=0.05$ ) number of species emerged from the 1year old deciduous slash than from the 4-year old slash (Fig. 4). However, there was a tendency for the opposite pattern in the coniferous slash $(U=$ $\left.43, n_{1 y r}=12, n_{4 y r}=12, p<0.12\right)$. Note that aspen, linden, rowan and willow were excluded from these statistical analyses due to the small sample sizes.

We compared the composition of the emerged Coleoptera in relation to tree species and age 
Table 4. Coleoptera emerged from 1-year and 4-year old slash. Four ecological groups distinguished (see text). $\mathrm{BS}=$ Betula species, PA = Picea abies, PS = Pinus sylvestris, PT = Populus tremula, QS = Quercus species, SA = Sorbus aucuparia.

\begin{tabular}{|c|c|c|c|c|c|c|c|c|c|c|}
\hline \multirow{2}{*}{$\begin{array}{l}\text { Age } \\
\text { Material type } \\
\text { Tree species }\end{array}$} & \multicolumn{2}{|c|}{$\begin{array}{c}1-y \\
\text { Conif. }\end{array}$} & \multicolumn{3}{|c|}{$\begin{array}{c}1-y \\
\text { Decid. }\end{array}$} & \multicolumn{2}{|c|}{$\begin{array}{c}4-y \\
\text { Conif. }\end{array}$} & \multicolumn{3}{|c|}{$\begin{array}{c}4-y \\
\text { Decid. }\end{array}$} \\
\hline & PA & PS & BS & QS & SA & PA & PS & BS & QS & PT \\
\hline \multicolumn{11}{|l|}{ Group 1} \\
\hline Tomicus minor (Hartig) & 2 & - & - & - & - & - & - & - & - & - \\
\hline Cryphalus abietis (Ratzeburg) & 5 & - & - & - & - & - & - & - & - & - \\
\hline Crypturgus hispidulus Thomson & 1 & - & - & - & - & - & - & - & - & - \\
\hline Pityogenes chalcographus (Linnaeus) & 258 & 47 & - & - & - & - & - & - & - & - \\
\hline Pityogenes bidentatus (Herbst) & 1 & 68 & - & - & - & - & - & - & - & - \\
\hline Pityophagus ferrugineus (Linnaeus) & - & 1 & - & - & - & - & - & - & - & - \\
\hline Orthotomicus suturalis (Gyllenhal) & - & 1 & - & - & - & - & - & - & - & - \\
\hline \multicolumn{11}{|l|}{ Group 2} \\
\hline Rhynchites cupreus (Linnaeus) & - & - & 1 & - & - & - & - & - & - & - \\
\hline Agrilus angustulus (Illiger) & - & - & - & 8 & - & - & - & - & - & - \\
\hline Magdalis barbicornis (Latreille) & - & - & - & - & 1 & - & - & - & - & - \\
\hline \multicolumn{11}{|l|}{ Group 3} \\
\hline Crypturgus pusillus (Gyllenhal) & - & - & - & - & - & 12 & - & - & - & - \\
\hline Phloeocharis subtilissima Mannerheim & - & - & - & - & - & 1 & - & - & - & _- \\
\hline Pityogenes quadridens (Hartig) & - & - & - & - & - & - & 7 & - & - & - \\
\hline Dasytes cyaneus Fabricius & - & - & - & - & - & - & 1 & - & - & - \\
\hline Dasytes aerosus Kiesenwetter & - & - & - & - & - & - & 1 & - & - & - \\
\hline Dromius spilotus (Illiger) & - & - & - & - & - & - & 1 & - & - & - \\
\hline \multicolumn{11}{|l|}{ Group 4} \\
\hline Leptusa ruficollis (Erichson) & - & - & - & - & - & - & - & 4 & - & 2 \\
\hline Rhizophagus dispar (Paykull) & - & - & - & - & - & - & - & 6 & 1 & 1 \\
\hline Synchita humeralis (Fabricius) & - & - & - & - & - & - & - & 1 & - & - \\
\hline Magdalis violacea (Linnaeus) & - & - & - & - & - & - & - & 1 & - & - \\
\hline Leiopus nebulosus (Linnaeus) & - & - & - & - & - & - & - & - & 16 & - \\
\hline Clytus arietis (Linnaeus) & - & - & - & - & - & - & - & - & 1 & - \\
\hline Total no. species & 5 & 4 & 1 & 1 & 1 & 2 & 4 & 4 & 3 & 2 \\
\hline
\end{tabular}

(Table 4). It appears that the emerged fauna could be separated into four distinct species groups: (1) early coniferous species, (2) early deciduous species, (3) late coniferous species, and (4) late deciduous species. In our material, no species were found in more than one of these species groups at a time (Table 4).

Coleoptera emerged from almost half (48\%) of the collected pieces of slash (Table 5). The mean percentage of slash with emerged Coleoptera from 4-year old clear-cuts exceeded the mean percentage from 1-year old clear-cuts: $54 \%$ versus $41 \%$, respectively (Table 5 ).

Despite the small sample size in this study, a considerable part of the collected slash harboured beetle individuals, indicating that logging residue on clear-cuts may function as an important re- source to the beetle fauna as breeding substrate and/or food supply. Recently, it has been suggested that the wood quality (e.g. age, moisture, decay state etc.) is of great importance to the overall composition of the beetle fauna in coarse woody debris (Jonsell \& Weslien 2003, Similä et al. 2003). The four distinct and separate speciesgroups found among Coleoptera in this study imply that wood quality is of importance also to the fauna within the fine fractions of woody debris.

The first group (Tomicus minor, Cryphalus abietis, Crypturgus hispidulus, Pityogenes chalcographus, Pityogenes bidentatus, Pityophagus ferrugineus and Orthotomicus suturalis), was found in fresh coniferous material (Table 4). Previous records for these species are similar according to faunistic records by Ehnström and 
Table 5. Slash data and emerged Coleoptera. Age = stand age (years since logging), Tree $=$ collected tree species, $\mathrm{N}=$ number of collected slash pieces, $\%$ Col. = percentage of slash pieces with beetles (absolute number in parentheses), Mass = mean dry mass $(\mathrm{kg})$ of slash per rearing tube (standard deviation in parentheses).

\begin{tabular}{llrll}
\hline Age & Tree & N & $\%$ Col. & \multicolumn{1}{l}{ Mass } \\
\hline 1 & Picea abies & 6 & $66.7(4)$ & $0.473(0.11)$ \\
1 & Pinus sylvestris & 6 & $66.7(4)$ & $0.441(0.20)$ \\
1 & Betula spp. & 6 & $16.7(1)$ & $0.418(0.12)$ \\
1 & Quercus spp. & 5 & $40(2)$ & $0.547(0.21)$ \\
1 & Populus tremula & 1 & $0(0)$ & $0.427(-)$ \\
1 & Tilia cordata & 1 & $0(0)$ & $0.094(-)$ \\
1 & Sorbus aucuparia & 3 & $33.3(1)$ & $0.418(0.21)$ \\
1 & Salix spp. & 1 & $0(0)$ & $0.173(-)$ \\
& Sum & 29 & $41(12)$ & \\
4 & Picea abies & 6 & $16.7(1)$ & $0.705(0.42)$ \\
4 & Pinus sylvestris & 6 & $50(3)$ & $0.331(0.04)$ \\
4 & Betula spp. & 6 & $66.7(4)$ & $0.488(0.28)$ \\
4 & Quercus spp. & 5 & $80(4)$ & $0.515(0.19)$ \\
4 & Populus tremula & 2 & $100(2)$ & $0.396(0.14)$ \\
4 & Sorbus aucuparia & 1 & $0(0)$ & $0.735(-)$ \\
& Sum & 26 & $54(14)$ & \\
\hline
\end{tabular}

Axelsson (2002) (Table 3). One exception was Tomicus minor that is usually exclusively found in pine but here it was recorded in spruce.

The second group (Rhynchites cupreus, Agrilus angustulus and Magdalis barbicornis), was found in recently dead branches of Betula, Quercus and Sorbus, respectively (Table 4). However, Rhynchites cupreus has earlier been found solely in Sorbus (Ehnström \& Axelsson 2002).

The third group (Crypturgus pusillus, Phloeocharis subtilissima, Dasytes aerosus, Dasytes cyaneus and Dromius spilotus), was found in old, softened coniferous branches (Table 4). Earlier findings of Dasytes aerosus and Dasytes cyaneus have been made in soft branches of Quercus, Tilia, Fagus and Fraxinus (Table 3 and Ehnström \& Axelsson 2002).

The fourth group (Leptusa ruficollis, Rhizophagus dispar, Synchita humeralis, Magdalis violacea, Leiopus nebulosus and Clytus arietis), was found in branches of Betula, Quercus and Populus. Earlier records of Magdalis violacea have been from coniferous material (Table 3 and Ehnström \& Axelsson 2002).

It is conceivable that these four distinct groups of the present study (Table 4) are due to the fact that several beetle species were recorded only once, in single specimens. Thus, possible variation in substrate preference is impossible to detect and quantify in our data.

Associations between beetles and particular material age or tree species is well known from faunistic studies (e.g. Ehnström \& Axelsson 2002). Our results imply that tree species and slash age is important not only for the species composition, but also for the number of species present. In the deciduous slash, significantly more species emerged from the 4-year old than from the 1-year old slash. However, in the coniferous material, we found only a slight tendency for more species in the 1-year old slash, compared to the 4-year old material. The lack of significance in the latter case might be due to the small sample size. The limited dataset also makes it difficult to analyze how the different age classes possibly differ in their species compositions. Hence, further studies are needed to evaluate the role of e.g. chemical substances like alcohols, terpenes and bark-beetle pheromones attracting beetles in different types of tree species and age classes of slash. Moreover, the exact timing of logging was unknown in the present study, yet this factor is known to influence the fauna composition notably (Ehnström \& Waldén 1986, Weslien 1992). 
According to Martikainen et al. (1996), decaying wood is predominantly comprised of downed logs and logging residue in managed forests. The authors also demonstrated that freshly man-made logging residues in disturbed and managed areas (i.e. clear-cuts) attract several Coleoptera, for example bark beetles. Our results support this, since bark beetles were predominant in the fresh (1-year old) slash left behind on clearcuts. Logging residue in Fennoscandian forests may provide an important resource for some Coleoptera, and there are reasons to believe that intensive, large-scale slash removals might increase the loss of species, populations and important habitats, with severe implications on biodiversity. Beetle species that are favoured by sunexposed fine branches on clear-cuts might decline due to the removal of logging residue. To our knowledge, there are no studies focusing on red-listed species that utilize slash in particular.

Insect rearings from various substrates are well known among entomologists. These methods are valuable because they provide exact information about the species microhabitat requirements and do not include any "tourist" species as do window and pitfall traps. However, most rearing methods have disadvantages (Økland 1996). For example, rearings are difficult to standardize and have low trapping efficiency, which makes it necessary to acquire large material. Despite the small sample size of the present study, insects emerged in $66 \%$ of all the rearing tubes and Coleoptera in $46 \%$ of the tubes. Rearings might thus be useful for quantifying the Coleoptera fauna dwelling in the finer fractions of various woody substrates left on clear-cuts. However, it is hard to judge whether the emerged specimens in our study were actually dwelling in the collected material, hibernating under bark, or were not discovered at all during the search-through by hand. Slash size is also likely to affect the results of our study. However, in the analyses we corrected for unequal slash size by relating the number of species to the dry weight of slash. Moreover, controlling for slash thickness may improve the method, e.g. by using a standardized thickness in rearings for comparisons of the species composition between age classes.

\section{Conclusions}

Our results imply that an ample part of the invertebrate fauna found on disturbed, sun-exposed sites like clear-cuts is utilizing slash. There were significantly more species in the 4-year old deciduous slash than in the 1-year old. Four different species groups were found in slash from the two age-classes ( 1 and 4 years) and five tree species. Bark beetles appeared to be the most prominent group in the 1-year old coniferous slash. At a local scale, removal of logging residue from clearcuts may have a negative effect on the beetle fauna dwelling in the finer fractions of the woody debris.

Acknowledgements. We thank Mattias Jonsson, Niklas Franc, Atte Komonen and an anonymous referee for valuable comments on the manuscript. Thomas Appelqvist helped us with some of the species determinations, and Bengt Ehnström discussed the rearing method. Thanks also to Björn Andreasson and Taisto Koivisto, the Forestry Department of Göteborg. The Swedish Energy Board, Helge Ax:son-Johnsons Stiftelse, Adlerbertska Forskningsstiftelsen, Wilhelm \& Martina Lundgrens Vetenskapsfond and Kungliga Vetenskapsakademien financed this project.

\section{References}

Egnell, G., Liedholm, H. \& Lönell, N. (eds.) 2001: Skogsbränsle, hot eller möjlighet? - Vägledning till miljövänligt skogsbränsleuttag. - Skogsstyrelsen, Jönköping [in Swedish]

Ehnström, B. \& Axelsson, R. 2002: Inseksgnag i bark och ved. - ArtDatabanken, SLU, Uppsala. [in Swedish]

Ehnström, B. \& Waldén, H. W. 1986: Faunavård i skogsbruket: Del 2 - Den lägre faunan. - Skogsstyrelsen, Jönköping. [in Swedish]

Fridman, J. \& Walheim, M. 2000: Amount, structure, and dynamics of dead wood on managed forestland in Sweden. - For. Ecol. Manage. 131: 23-36.

Jonsell, M. 1999: Insects in wood-decaying polypores: Conservation aspects. - Ph.D. Thesis, Acta Universitatis Agriculturae Sueciae, SLU, Uppsala.

Jonsell, M. \& Weslien, J. 2003: Felled or standing retained wood - it makes a difference for saproxylic beetles. — For. Ecol. Manage. 175: 425-435.

Jonsell, M., Weslien, J. \& Ehnström, B. 1998: Substrate requirements of red-listed saproxylic invertebrates in Sweden. - Biodivers. Conserv. 7: 749-764.

Jonsson, M., Nordlander, G. \& Jonsell, M. 1997: Pheromones affecting flying beetles colonizing the polypores. - Entomologica Fennica 8: 161-165.

Komonen, A. 2003: Hotspots of insect diversity in boreal forests. - Conserv. Biol. 17: 976-981. 
Komonen, A., Penttilä, R., Lindgren, M. \& Hanski, I. 2000: Forest fragmentation truncates a food chain based on an old-growth forest bracket fungus. - Oikos 90: 119-126.

Martikainen, P. \& Kouki, J. 2003: Sampling the rarest: threatened beetles in boreal forest biodiversity inventories. - Biodivers. Conserv. 12: 1815-1831.

Martikainen, P., Siitonen, J., Kaila, L. \& Punttila, P. 1996: Intensity of forest management and bark beetles in non-epidemic conditions: a comparison between Finnish and Russian Karelia. - Journal of Applied Entomology 120: 257-264.

Økland, B. 1996: A comparison of three methods of trapping saproxylic beetles. - European Journal of Entomology 93: 195-209.

Palm, T. 1959: Die Holz- und Rinden-käfer der Süd- und Mittelswedishen Laubbäume. - Opuscula Entomologica Supplementum XVI, Lund. [in German]

Pettersson, T. 1974: Insektsproduktionen i hyggesavfall. — Rapport nr. 4-74, Statens skogsmästarskola, Skinnskatteberg. [in Swedish]

SAS. Institute Inc. 1998: StatView Reference. — SAS In- stitute Inc., Cary, NC.

Schroeder, L. M. \& Eidmann, H. H. 1993: Attacks of barkand wood-boring Coleoptera on snow-broken conifers over a two-year period. — Scand. J. For. Res. 8: 257265.

Siitonen, J., Martikainen, P., Punttila, P. \& Rauh, J. 2000: Coarse woody debris and stand characteristics in mature managed and old-growth boreal mesic forests in southern Finland. - For. Ecol. Manage. 128: 211225.

Similä, M., Kouki, J. \& Martikainen, P. 2003: Saproxylic beetles in managed and seminatural Scots pine forests: quality of dead wood matters. - For. Ecol. Manage. 174: 365-381.

Similä, M., Kouki, J., Martikainen, P. \& Uotila, A. 2002: Conservation of beetles in boreal pine forests: the effect of forest age and naturalness on species assemblages. - Biol. Conserv. 106: 19-27.

Weslien, J. 1992: The arthropod complex associated with Ips typographus (L.) (Coleoptera, Scolytidae), species composition, phenology, and impact on bark beetle productivity. - Entomologica Fennica 3: 205-213. 